\title{
Degree of phosphate saturation in highly weathered tropical soils
}

\author{
Murilo de Campos ${ }^{\mathrm{a}}$, João Arthur Antonangelo ${ }^{\mathrm{b}}$, Sjoerd E.A.T.M. van der Zee ${ }^{\mathrm{c}}$, \\ Luís Reynaldo Ferracciú Alleoni ${ }^{\text {d,* }}$ \\ a Department of Crop Science, Lageado Farm, Sao Paulo State University, 1780 Jose Barbosa de Barros, Botucatu, SP, 18610-307, Brazil \\ b Plant and Soil Sciences Department, Oklahoma State University Stillwater, 039 Agricultural Hall, OK, 74078, United States \\ ${ }^{\mathrm{c}}$ Department of Environmental Sciences, Soil Physics and Land Management, Wageningen University, 6708 PB Wageningen and/or School of Chemistry, Monash \\ University, Melbourne, VIC, Australia \\ ${ }^{\mathrm{d}}$ Soil Science Department, Luiz de Queiroz College of Agriculture, University of Sao Paulo, 11 Padua Dias, Piracicaba, SP, 13418-900, Brazil
}

\section{A R T I C L E I N F O}

\section{Keywords:}

Loss of $\mathrm{P}$

Scaling factor $\alpha$

Degree of P saturation

Sorption capacity of $\mathrm{P}$

Principal component analysis

\begin{abstract}
A B S T R A C T
The degree of phosphate saturation (DPS) is an indicator for P-saturation, which is of assistance to the prediction of $P$ losses and potential eutrophication of surface water. The scaling factor $(\alpha)$ estimates the adsorption capacity of the soil and is used to calculate the DPS. In soils from temperate regions, the value of $\alpha=0.5$ is widely used. However, using just a single value for $\alpha$ may fail to estimate the adsorption capacity correctly for all soils. In this study, the aims were (i) to calculate the scaling factor $\alpha$ and the DPS of highly weathered tropical soils with different chemical, physical and mineralogical properties in order to predict P losses; and (ii) to identify which soil properties are related to P adsorption. The scaling factor $\alpha$ and the DPS were calculated at 1, 3, 7, 21, 42 and 84 days (d), the highest one in recognition of the long-term kinetics of sorption. The values of $\alpha$ increased as the contact period increased. Lower DPS values were obtained in soils with high P adsorption capacity whereas the highest DPS values were obtained in soils with a lower adsorption capacity. Out of ten Oxisols studied, six of them had an $\alpha$ higher than 1 . Contents of clay, organic carbon $(\mathrm{C})$ and poorly crystalline $\left(\mathrm{Al}_{\mathrm{ox}}\right)$ and crystalline ("free") $\mathrm{Al}$ oxides were the properties that best correlated with $\mathrm{P}$ adsorption. For the Oxisols, the clay content, poorly crystalline together with crystalline $\mathrm{Fe}$ and $\mathrm{Al}$ oxides represented the main components related to $\mathrm{P}$ adsorption. The highest DPS (31\%) was found in Typic Udorthent. The content of poorly crystalline oxides was not suitable for the scaling factor $\alpha$ for most Oxisols, and only the Typic Udorthent exceeded the critical threshold of $23 \%$, and is thus more susceptible to loss of P.
\end{abstract}

\section{Introduction}

The degree of phosphate saturation (DPS) is an indicator of the risk of loss of P from soil. Such losses are mainly a consequence of runoff and eventual leaching. The DPS has been used in countries such as the Netherlands (Van Der Zee and Van Riemsdijk, 1988), Germany, (Freese et al., 1992; Freese et al., 1995), Belgium (Lookman et al., 1995; Lookman et al., 1996), Ireland (Maguire et al., 2001), the United States (Paulter and Sims, 2000; Nair et al., 2004), and Canada (Ige et al., 2005). A major motivation for its use has been the risk of accumulation of $\mathrm{P}$ in surface waters in regions with relatively intensive animal husbandry. In contrast to temperate regions, humid tropical regions have highly weathered soils, high contents of $\mathrm{Fe}, \mathrm{Al}$ and $\mathrm{Mn}$ hydroxides, and 1:1 aluminosilicates minerals with a strong tendency to adsorb $\mathrm{P}$ (Mesquita Filho and Torrent, 1993).

Because soils have a P critical saturation level, above which too much leaching may occur (Van Der Zee, 1988), the DPS becomes important as long as it is a potential indicator of contamination risk in the case of further P additions (Paulter and Sims, 2000). When determining the DPS level, the P content already present in the soil $\left(\mathrm{P}_{\mathrm{ox}}\right)$ in relation to the maximum retention capacity has to be taken into consideration, principally when it correlates positively with the P dissolved in the runoff and the leached solutions (Liu et al., 2012; Wang et al., 2010).

The $\mathrm{P}$ sorption index (PSI) is a tool for assessing the potential of $\mathrm{P}$ to move from agricultural fields to surface water and indicates the current $\mathrm{P}$ adsorption capacity based on a single point from an adsorption isotherm (soil as sampled). The P sorption capacity (PSC) is a parameter which estimates the maximum amount of $\mathrm{P}$ that a given soil is able to adsorb. It is calculated by using the sum of the PSI and the content of P extracted by ammonium oxalate $\left(\mathrm{P}_{\mathrm{ox}}\right)$. In this respect, the use of a saturation index, known as a scaling factor $\alpha$ is convenient as it directly relates the amount of $\mathrm{P}$ adequately sorbed to those soil properties that determine sorption. This factor is calculated as the molar ratio of the

\footnotetext{
* Corresponding author.

E-mail address: alleoni@usp.br (L.R.F. Alleoni).
} 
PSC (mmol kg-1) over the sum of the poorly crystallized content ("amorphous") of $\mathrm{Fe}$ and $\mathrm{Al}$ extracted by an acid solution of ammonium oxalate $\left(\mathrm{Fe}_{\mathrm{ox}}\right.$ and $\mathrm{Al}_{\mathrm{ox}}$ in $\left.\mathrm{mmol} \mathrm{kg} \mathrm{kg}^{-1}\right)$, which can be regarded as a critical value of the DPS (Maguire et al., 2001). In this respect, the latter is based on the amount of $\mathrm{P}$ adsorbed to a soil at the moment that the soil is sampled, i.e., without further P adsorption in the lab. If oxalate extractable $\mathrm{Fe}$ and $\mathrm{Al}$ control $\mathrm{P}$-sorption, the DPS relates $\mathrm{P}$ already adsorbed by a soil to its $\mathrm{P}$ adsorption capacity.

The value of $\alpha=0.5$ has been widely used for soils found in temperate regions (Van Der Zee and Van Riemsdijk, 1988; Schoumans, 2009). The use of only a single $\alpha$ value, however, implies that all soils have a similar molar ratio (PSC/( $\left.\mathrm{Fe}_{\mathrm{ox}}+\mathrm{Al}_{\mathrm{ox}}\right)$ ). Beauchemin and Simard (1999) suggest that it is necessary to establish different values of $\alpha$ for groups or types of soils or even a separate value for each soil. In Brazil, DPS and saturation indexes have hardly been investigated, and it has not been established whether different soil types would be better characterized with different $\alpha$ values, in order to identify environmental risk. The scope of this paper is to determine $\alpha$ values for highly weathered tropical soils with different properties than those investigated so far and relate the scaling parameters with such properties. Consequently, by relating the DPS to certain of the soil properties in tropical humid regions, it may be possible to generalize the risk assessment to locations where soil map information is available, but where $\alpha$ has not been experimentally determined.

Our purpose was to calculate the parameterś scaling factor $\alpha$, PSC and DPS for highly weathered tropical soils with different chemical, physical and mineralogical properties, and identify which soil properties are related to the DPS, PSC and P sorption index (PSI) by using the principal component analysis technique (PCA). We also selected those soils with high susceptibility to $\mathrm{P}$ losses and high potential for surface water eutrophication.

\section{Materials and methods}

A total of 29 soil samples from the topsoil layer $(0-20 \mathrm{~cm})$ with different chemical, physical and mineralogical properties were collected in forest, native and riparian forests and old reforestation in the state of Sao Paulo, Brazil, which had not been fertilized with either organic manure or commercial fertilizers. Soil samples were classified under the following soil types: Oxisols, Ultisols, Alfisols, Entisols, Inceptisols, Histosols and Mollisols (Soil Survey Staff, 1999).

Soil samples were chemically characterized using air-dried soil passed through a 2 -mm sieve (10 mesh). Carbon content (C) was determined by a modified Walkley-Black method (Nelson and Sommer, 1982). Organic carbon content was measured in soil samples passed through a 100-mesh sieve after oxidation of organic matter in the soil with $0.167 \mathrm{M}$ potassium dichromate solution $\left(\mathrm{K}_{2} \mathrm{Cr}_{2} \mathrm{O}_{7}\right)$ in the presence of concentrated sulfuric acid (Nelson and Sommer, 1982). Particle size analysis to determine the clay content was based on the hydrometer method (Gee and Or, 2002). The Fe and Al crystalline oxide contents were obtained by reacting the soil sample with a sodium dithionitecitrate-bicarbonate solution (Mehra and Jackson, 1960) and determined by atomic absorption spectrophotometry (AAS). The poorly crystallized forms of $\mathrm{Fe}, \mathrm{Al}$ and $\mathrm{P}$ were extracted using $0.1 \mathrm{M}$ oxalic acid solution $+0.2 \mathrm{M}$ ammonium oxalate at $\mathrm{pH}=3.0$ (Schoumans, 2009) and determined by Inductively Coupled Plasma - Optical Emission Spectrometry (ICP-OES). In addition, the bioavailable $\mathrm{P}$ content was extracted by Mehlich 1 solution $\left(0.0125 \mathrm{M} \mathrm{H}_{2} \mathrm{SO}_{4}+0.05 \mathrm{M} \mathrm{HCl}\right)$ and water (Kuo, 1996).

\subsection{Phosphorus sorption index}

The PSI was calculated in order to determine the addition of a single amount of P (Bache and Williams, 1971). Therefore, $2.5 \mathrm{~g}$ of air-dried and 2 -mm sieved soil samples were given $25 \mathrm{~mL} 0.01 \mathrm{M} \mathrm{CaCl}_{2}$ (supporting electrolyte) with rates of $\mathrm{P}\left(\mathrm{KH}_{2} \mathrm{PO}_{4}\right)$ calculated from the maximum $\mathrm{P}$ adsorption capacity $\left(\mathrm{S}_{\max }\right)$, previously measured by Langmuir isotherm (data not shown). The samples were divided into five groups, and the soils within each group received a concentration of $\mathrm{P}$ in proportion to their adsorption capacity (de Campos et al., 2016). The groups were divided as follows: I - Very high adsorption capacity $\left(\mathrm{S}_{\max }>2000 \mathrm{mg} \mathrm{kg}^{-1}\right)$; II - High adsorption capacity $\left(\mathrm{S}_{\max }\right.$ between 1000 to $2000 \mathrm{mg} \mathrm{kg}^{-1}$ ); III - Medium adsorption capacity ( $S_{\max }$ between 500 and $1000 \mathrm{mg} \mathrm{kg}^{-1}$ ); IV - Low adsorption capacity $\left(S_{\max }\right.$ between 200 and $500 \mathrm{mg} \mathrm{kg}^{-1}$ ); and $\mathrm{V}$ - very low adsorption capacity $\left(\mathrm{S}_{\max }<200 \mathrm{mg} \mathrm{kg}^{-1}\right)$. The conversions into $\mathrm{mmol} \mathrm{kg}^{-1}$ of $\mathrm{P}$ and $\mathrm{PO}_{4}{ }^{3-}$ are presented in the Appendix A.

The maximum contact period of samples in order to calculate the PSI was $84 \mathrm{~d}$ (12 weeks). During this period, P concentrations in solution were assessed at 1, 3, 7, 21, 42 and $84 \mathrm{~d}$. The samples were analyzed in triplicate for each reaction period, and stirred daily for $2 \mathrm{~h}$ in a horizontal shaker at $150 \mathrm{osc} \mathrm{min}^{-1}$ after the first $24 \mathrm{~h}$ of stirring. After that, the samples were centrifuged at $1844 \times g$ for $15 \mathrm{~min}$, and an aliquot of the extract was taken to determine the P content by colorimetry (Murphy and Riley, 1962). The adsorbed P was calculated as the difference between the $\mathrm{P}$ added and the $\mathrm{P}$ remaining in the solution, and the PSI calculated using Eq. (1) as follows:

PSI $\left(\mathrm{mmol} \mathrm{kg}^{-1}\right)=[\mathrm{X} /(\log \mathrm{C}) /(30.97)]$

where: $\mathrm{X}=\mathrm{P}$ adsorbed $\left(\mathrm{mg} \mathrm{kg}^{-1}\right)=\left(\mathrm{P}_{\mathrm{i}}-\mathrm{P}_{\mathrm{f}}\right) \times(0.025 \mathrm{~L}) /(0.0025 \mathrm{~kg}$ soil); $\mathrm{P}_{\mathrm{i}}=$ Initial $\mathrm{P}$ concentration $\left(\mathrm{mg} \mathrm{L}^{-1}\right) ; \mathrm{P}_{\mathrm{f}}=$ Final concentration of $\mathrm{P}$ in the equilibrium solution $\left(\mathrm{mg} \mathrm{L}^{-1}\right) ; \mathrm{C}=$ Concentration of $\mathrm{P}$ at the reaction time when measured $\left(\mathrm{mg} \mathrm{L}^{-1}\right)$; and $30.97=$ phosphorus molar mass.

\subsection{Scaling factor $\alpha$ and degree of phosphorus saturation}

The scaling factor $\alpha$ was estimated by using the equation described in Van Der Zee and Van Riemsdijk (1988):

$\alpha=\left(\mathrm{PSI}_{84 \mathrm{~d}}+\mathrm{P}_{\mathrm{ox}}\right) /\left(\mathrm{Al}_{\mathrm{ox}}+\mathrm{Fe}_{\mathrm{ox}}\right)$

where $\mathrm{PSI}_{84 \mathrm{~d}}$ is the $\mathrm{P}$ sorption index at $84 \mathrm{~d}$ of reaction $\left(\mathrm{mmol} \mathrm{kg}^{-1}\right)$, $\mathrm{Al}_{\mathrm{ox}}+\mathrm{Fe}_{\mathrm{ox}}$ correspond to the amount of poorly crystallized oxides of $\mathrm{Fe}$ and $\mathrm{Al}$, and $\mathrm{P}_{\mathrm{ox}}$ is the $\mathrm{P}$ content linked to oxides.

In the $\alpha$ calculation, the PSI $84 \mathrm{~d}$ was adopted as the index of soil adsorption capacity in the long-term. The $\mathrm{P}_{\mathrm{ox}}$ levels were deemed to estimate the $\mathrm{P}$ sorption capacity $\left(\mathrm{PSC}=\mathrm{PSI}_{84 \mathrm{~d}}+\mathrm{P}_{\mathrm{ox}}\right.$ ), where $\mathrm{P}_{\mathrm{ox}}$ is the amount of $\mathrm{P}$ already adsorbed to the poorly crystalline structures. Thus, we followed an approach that was different from McGechan and Lewis (2002), who disregarded P already adsorbed by soil.

The DPS (\%) was calculated as the ratio of the $\mathrm{P}_{\text {ox }}$ content already accumulated in the top soil $(0.0-0.2 \mathrm{~m})$ to the $\mathrm{P}$ sorption capacity given by $\mathrm{PSC}=\mathrm{P}_{\mathrm{ox}}+\mathrm{PSI}_{84 \mathrm{~d}}$ (Van Der Zee and Van Riemsdijk, 1988), i.e.,

DPS $(\%)=100 * \mathrm{P}_{\text {ox }} /$ PSC

\subsection{Statistical analysis}

The correlations between soil properties and DPS, PSI and PSC were evaluated by principal component and cluster analyses (PCA and Cluster, respectively) in order to identify the soil properties best correlated with the studied variables. PCA is a multivariate statistical method that aims to explain the major part of variations in data from a smaller number of components, which are linear combinations of the properties (Anderson, 2003). Multivariate analyses and multiple regressions were performed using the Statistica software program (Statsoft, 2005). The criteria used to determine the factors followed the Kaiser Rule, taking into account eigenvalues $\geq 1$ to explain over $85 \%$ of the total variance (Kaiser, 1958). Correlations had to be $\geq|0.70|$ to be considered (Manly, 1994). 
Table 1

Chemical, physical and mineralogical properties of the soils.

\begin{tabular}{|c|c|c|c|c|c|c|c|c|c|c|}
\hline \multirow[t]{2}{*}{ Soil } & \multirow[t]{2}{*}{ Coordinates } & \multirow{2}{*}{\multicolumn{2}{|c|}{ 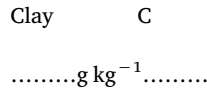 }} & \multirow{2}{*}{\multicolumn{2}{|c|}{$\begin{array}{l}\mathrm{P}_{\mathrm{M} 1} \mathrm{P}_{\mathrm{H} 2 \mathrm{O}} \\
\ldots \ldots \ldots \mathrm{mg} \mathrm{kg}^{-1} \ldots \ldots \ldots\end{array}$}} & \multirow{2}{*}{\multicolumn{2}{|c|}{$\begin{array}{l}\mathrm{Fe}_{\mathrm{DCB}} \mathrm{Al}_{\mathrm{DCB}} \\
\ldots \ldots \ldots \mathrm{mmol} \mathrm{kg}^{-1} \ldots \ldots \ldots\end{array}$}} & \multirow{2}{*}{\multicolumn{2}{|c|}{$\begin{array}{ll}\mathrm{Fe}_{\mathrm{ox}} / & \mathrm{Al}_{\mathrm{ox}} / \\
\mathrm{Fe}_{\mathrm{DCB}} & \mathrm{Al}_{\mathrm{DCB}} \\
\ldots \ldots \ldots \% \ldots \ldots \ldots\end{array}$}} & \multirow[t]{2}{*}{ Qualitative Mineralogy } \\
\hline & & & & & & & & & & \\
\hline Arenic Hapludox & $22^{\circ} 19^{\prime} \mathrm{S} 47^{\circ} 10^{\prime} \mathrm{W}$ & 181 & 8 & 5.7 & 1 & 340.9 & 134.9 & 1 & 11 & $\mathrm{Kt}, \mathrm{Gt}, \mathrm{Hm}$ \\
\hline Typic Hapludox-1 & $22^{\circ} 15^{\prime} \mathrm{S} 47^{\circ} 49^{\prime} \mathrm{W}$ & 221 & 14 & 11.5 & 1.3 & 236.7 & 116.8 & 2 & 21 & $\mathrm{Kt}, \mathrm{Gt}, \mathrm{Hm}$ \\
\hline Typic Hapludox-2 & $22^{\circ} 19^{\prime} \mathrm{S} 47^{\circ} 10^{\prime} \mathrm{W}$ & 202 & 8 & 6.3 & 1 & 373.1 & 172.6 & 1 & 12 & $\mathrm{Kt}, \mathrm{Gt}, \mathrm{Hm}$ \\
\hline Rhodic Hapludox-1 & $22^{\circ} 01^{\prime} \mathrm{S} 47^{\circ} 53^{\prime} \mathrm{W}$ & 201 & 10 & 12.5 & 2.8 & 939.8 & 274.2 & 1 & 8 & $\mathrm{Kt}, \mathrm{Gb}, \mathrm{Gt}, \mathrm{Hm}$ \\
\hline Rhodic Hapludox-2 & $21^{\circ} 05^{\prime} \mathrm{S} 47^{\circ} 08^{\prime} \mathrm{W}$ & 530 & 24 & 5.9 & 2.8 & 1529.1 & 405.5 & 1 & 19 & $\mathrm{Kt}, \mathrm{Gt}, \mathrm{Hm}$ \\
\hline Rhodic Eutrudox & $22^{\circ} 43^{\prime} \mathrm{S} 47^{\circ} 38^{\prime} \mathrm{W}$ & 684 & 50 & 19 & 5 & 3277.9 & 311.2 & 1 & 29 & $\mathrm{Kt}, \mathrm{Gb}, \mathrm{Hm}$ \\
\hline Rhodic Acrudox & $21^{\circ} 10^{\prime} \mathrm{S} 47^{\circ} 48^{\prime} \mathrm{W}$ & 716 & 14 & 3.7 & 0.7 & 3680.1 & 940.3 & 1 & 8 & $\mathrm{Kt}, \mathrm{Gb}, \mathrm{Gt}, \mathrm{Hm}$ \\
\hline Xanthic Hapludox-1 & $22^{\circ} 15^{\prime} \mathrm{S} 47^{\circ} 49^{\prime} \mathrm{W}$ & 222 & 24 & 13.6 & 1.8 & 334.4 & 259.6 & 3 & 13 & $\mathrm{Kt}$ \\
\hline Xanthic Hapludox-2 & $21^{\circ} 57^{\prime} \mathrm{S} 47^{\circ} 59^{\prime} \mathrm{W}$ & 342 & 14 & 4.5 & 1 & 745.2 & 309.7 & 1 & 11 & $\mathrm{Kt}, \mathrm{Gb}, \mathrm{Gt}$ \\
\hline Xanthic Acrudox & $20^{\circ} 10^{\prime} \mathrm{S} 48^{\circ} 02^{\prime} \mathrm{W}$ & 470 & 24 & 5.3 & 3.7 & 2001.2 & 568.6 & 1 & 16 & $\mathrm{Kt}, \mathrm{Gb}, \mathrm{Gt}, \mathrm{Hm}$ \\
\hline Arenic Hapludult-1 & $22^{\circ} 32^{\prime} \mathrm{S} 47^{\circ} 54^{\prime} \mathrm{W}$ & 60 & 4 & 6.1 & 1.4 & 61 & 55.6 & 2 & 9 & $\mathrm{Kt}$ \\
\hline Arenic Hapludult-2 & $22^{\circ} 38^{\prime} \mathrm{S} 47^{\circ} 11^{\prime} \mathrm{W}$ & 100 & 4 & 19.8 & 2.6 & 92.6 & 40.9 & 1 & 12 & Kt, Il \\
\hline Typic Hapludult-1 & $22^{\circ} 43^{\prime} \mathrm{S} 47^{\circ} 38^{\prime} \mathrm{W}$ & 247 & 20 & 47.3 & 4.8 & 575.3 & 202.9 & 1 & 11 & $\mathrm{Kt}, \mathrm{Gt}, \mathrm{Hm}$ \\
\hline Typic Hapludult-2 & $22^{\circ} 17^{\prime} \mathrm{S} 49^{\circ} 33^{\prime} \mathrm{W}$ & 202 & 9 & 9.7 & 1.7 & 142.8 & 72.8 & 5 & 20 & Kt, Il \\
\hline Typic Hapludult-3 & $22^{\circ} 06^{\prime} \mathrm{S} 46^{\circ} 40^{\prime} \mathrm{W}$ & 366 & 19 & 32.3 & 6.8 & 792 & 57.6 & 2 & 32 & Kt, Il, VHE \\
\hline Typic Hapludult-4 & $22^{\circ} 43^{\prime} \mathrm{S} 47^{\circ} 38^{\prime} \mathrm{W}$ & 246 & 23 & 9.2 & 3.4 & 564.4 & 204.9 & 2 & 13 & $\mathrm{Kt}, \mathrm{Gt}, \mathrm{Hm}$ \\
\hline Rhodic Hapludult-1 & $22^{\circ} 12^{\prime} \mathrm{S} 49^{\circ} 56^{\prime} \mathrm{W}$ & 100 & 4 & 6.6 & 1.2 & 148.3 & 57.8 & 1 & 13 & $\mathrm{Kt}$, Il \\
\hline Rhodic Hapludult-2 & $22^{\circ} 59^{\prime} \mathrm{S} 47^{\circ} 30^{\prime} \mathrm{W}$ & 427 & 22 & 6.3 & 2.5 & 873.5 & 214.4 & 3 & 12 & $\mathrm{Kt}, \mathrm{Gt}, \mathrm{Hm}$ \\
\hline Typic Quartzipsamment & $22^{\circ} 32^{\prime} \mathrm{S} 47^{\circ} 54^{\prime} \mathrm{W}$ & 80 & 6 & 6.2 & 0.9 & 49.7 & 85.6 & 4 & 10 & $\mathrm{Kt}$ \\
\hline Typic Udorthent & $22^{\circ} 12^{\prime} \mathrm{S} 49^{\circ} 39^{\prime} \mathrm{W}$ & 142 & 13 & 22.5 & 2.9 & 113.8 & 49.1 & 9 & 25 & Il, VHE \\
\hline Typic Psammaquent & $22^{\circ} 26^{\prime} \mathrm{S} 49^{\circ} 45^{\prime} \mathrm{W}$ & 101 & 8 & 12.2 & 2 & 192.4 & 44.6 & 2 & 18 & Kt, Il \\
\hline Typic Rhodudalf & $22^{\circ} 59^{\prime} \mathrm{S} 47^{\circ} 30^{\prime} \mathrm{W}$ & 345 & 29 & 5.1 & 3.2 & 1498.5 & 767.3 & 1 & 7 & $\mathrm{Kt}, \mathrm{Gb}$ \\
\hline Rhodic Eutrudalf & $22^{\circ} 06^{\prime} \mathrm{S} 47^{\circ} 07^{\prime} \mathrm{W}$ & 658 & 29 & 6 & 6 & 3407.7 & 379.9 & 1 & 22 & $\mathrm{Kt}, \mathrm{Gb}, \mathrm{Hm}$ \\
\hline Typic Fluvaquent & $24^{\circ} 43^{\prime} \mathrm{S} 47^{\circ} 52^{\prime} \mathrm{W}$ & 532 & 33 & 35.3 & 2.6 & 377.4 & 1490.6 & 13 & 3 & $\mathrm{Kt}, \mathrm{Gt}, \mathrm{Hm}$ \\
\hline Mollic Fluvaquent & $21^{\circ} 10^{\prime} \mathrm{S} 47^{\circ} 48^{\prime} \mathrm{W}$ & 476 & 103 & 27.9 & 0.9 & 62.1 & 754.8 & 16 & 46 & $\mathrm{Kt}$ \\
\hline Typic Haplustept & $22^{\circ} 07^{\prime} \mathrm{S} 47^{\circ} 39^{\prime} \mathrm{W}$ & 243 & 16 & 7.1 & 0.7 & 335.3 & 257 & 2 & 16 & $\mathrm{Kt}$ \\
\hline Typic Albaqualf & $22^{\circ} 42^{\prime} \mathrm{S} 47^{\circ} 38^{\prime} \mathrm{W}$ & 204 & 12 & 8.7 & 1.4 & 303.6 & 56.4 & 5 & 30 & Kt, Il \\
\hline Typic Haploxeralf & $22^{\circ} 22^{\prime} \mathrm{S} 46^{\circ} 56^{\prime} \mathrm{W}$ & 40 & 4 & 8.7 & 1.8 & 142.6 & 33.4 & 2 & 14 & Kt, Il, VHE \\
\hline Typic Argiudoll & $22^{\circ} 08^{\prime} \mathrm{S} 47^{\circ} 40^{\prime} \mathrm{W}$ & 543 & 28 & 12.3 & 3.1 & 1905.2 & 281.7 & 3 & 26 & $\mathrm{Kt}, \mathrm{Gt}, \mathrm{Hm}$ \\
\hline
\end{tabular}

$\mathrm{Kt}=$ Kaolinite; $\mathrm{Gt}=$ Goethite; $\mathrm{Hm}=$ Hematite; $\mathrm{Gb}=$ Gibbsite; $\mathrm{Il}=$ Ilite e HIV = hydroxy-interlayered vermiculite.

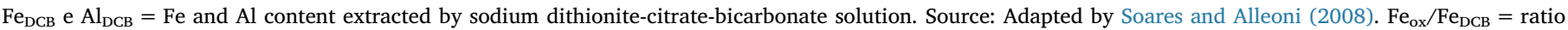
between $\mathrm{Fe}_{\mathrm{ox}} / \mathrm{Fe}_{\mathrm{DCB}} ; \mathrm{Fe}_{\mathrm{DCB}}-\mathrm{Fe}_{\mathrm{ox}}=$ Crystalline $\mathrm{Fe}$.

Organic Matter $=$ Walkley-Black method; $\mathrm{P}_{\mathrm{M} 1}=$ Phosphorus extracted with Mehlich-1; $\mathrm{P}_{\mathrm{H} 2 \mathrm{O}}=$ Soluble phosphorus on water.

Clay $=$ hydrometer method (Boyoucos).

\section{Results and discussion}

Basic properties that characterize the soils are given in Table 1 . More detailed information regarding the electro(chemical), physical and mineralogical properties of the 29 soils can be found in Soares and Alleoni (2008).

From Eq. (2), it is possible to infer an $\alpha$ value of 0.80 , on average, a reaction time of $84 \mathrm{~d}$ (Table 2), which is probably due to the increase in PSI values caused by continued adsorption in longer contact periods. In the Netherlands, Van Der Zee and Van Riemsdijk (1988) evaluating acidic, and sandy soils with low organic matter content reported a mean value of $\alpha=0.48$ at $40 \mathrm{~h}$ of contact and $\alpha=0.61$ after $249 \mathrm{~d}$. Maguire et al. (2001) found mean values for $\alpha$ that ranged from 0.31 at $18 \mathrm{~h}$ to 0.65 at $249 \mathrm{~d}$ contact time in acidic, sandy and medium textured soils in Ireland.

The values of $\alpha$ obtained for the longest contact period ranged from 0.29 in Typic Udorthent to 1.77 in Xanthic Hapludox-2 (Table 2). In Oxisols, $\alpha$ values ranged from 0.53 in Typic Hapludox-1 to 1.77 in Xanthic Hapludox-2. The Oxisols had a high P adsorption capacity due to higher levels of $\mathrm{Fe}$ and $\mathrm{Al}$ crystalline oxides $\left(\mathrm{Fe}_{\mathrm{DCB}}\right.$ and $\mathrm{Al}_{\mathrm{DCB}}$ ) (Table 1). Out of ten investigated Oxisols, six were characterized with $\alpha>1$ at $84 \mathrm{~d}$ of contact, which sets this soil type apart from the others in terms of its P-reactivity.

The $\alpha>1$ values indicate that the poorly crystalline oxides did not represent the main soil mineral compound that is related to adsorption. The adsorption capacity in Oxisols also depends on crystalline oxides and type of 1:1 silicate minerals. Diffraction X-ray (DRX) analysis indicated the presence of kaolinite, a 1:1 silicate mineral commonly found in humid tropical soils, and gibbsite, an Al hydroxide with a high affinity for adsorbing P (Fontes and Weed, 1996) in addition to hematite and goethite (Table 1), also with a high affinity for $\mathrm{P}$ adsorption. In the other soils, the values of $\alpha$ were less than 1 . Pautler and Sims (2000) and Maguire et al. (2001) showed that values of $\alpha<1$ were found even for P-saturated soils. Unlike values of about $\alpha=0.5$ that were found in other studies (De Smet et al., 1996; Schoumans, 2009; Borda et al., 2011; De Bolle et al., 2013; Alleoni et al., 2014), the values for humid tropical soils had a sizeable greater variation of $\mathrm{P}_{\mathrm{ox}}$, $\mathrm{Fe}_{\mathrm{ox}}$ and $\mathrm{Al}_{\mathrm{ox}}$.

There was less variation in the $\alpha$ values of Alfisols (0.8 in Rhodic Eutrudalf and 0.91 in Typic Rhodudalf) and Gleysols (0.55 in Mollic Fluvaquent and 0.60 in Typic Fluvaquent) than in the other soil types. In the Ultisols, the value of $\alpha$ ranged from 0.39 in Typic Hapludult- 2 to 0.96 in Arenic Hapludult-2 and in the Entisols, from 0.29 in Typic Udorthent to 0.87 in Typic Quartzipsamment. This shows significant variation even within the same soil type, and the disputable value of assuming that $\alpha$ always has the same standard value of 0.5 . Because $\alpha$ may differ from one soil type to another, the calculation of DPS using one value is likely to give meaningless results. An additional error in estimating DPS or PSC using standardized values of $\mathrm{Fe}_{\mathrm{ox}}$ and $\mathrm{Al}_{\mathrm{ox}}$ for each soil type may be because the oxide contents are valid for a different layer thickness other than the $0.2 \mathrm{~m}$ thick layers as used in this investigation, for instance.

Fig. 1a shows the correlation between the sum of the oxides $\left(\mathrm{Fe}_{\mathrm{ox}}+\mathrm{Al}_{\mathrm{ox}}\right)$ and the PSC of all soils. As discussed earlier, poorly crystallized oxides did not completely explain the P sorption capacity, in view of $\alpha$ values greater than one $(\alpha>1)$ for the Oxisols. Thus, Fig. 1b shows the correlation between the sum of the oxides $\left(\mathrm{Fe}_{\mathrm{ox}}+\mathrm{Al}_{\mathrm{ox}}\right)$ and the PSC excluding the Oxisols. An improved straightline fit was obtained when Oxisols were removed from the data set, with a higher coefficient of determination $\left(\mathrm{R}^{2}=0.96\right)$ (Fig. 1b). This 


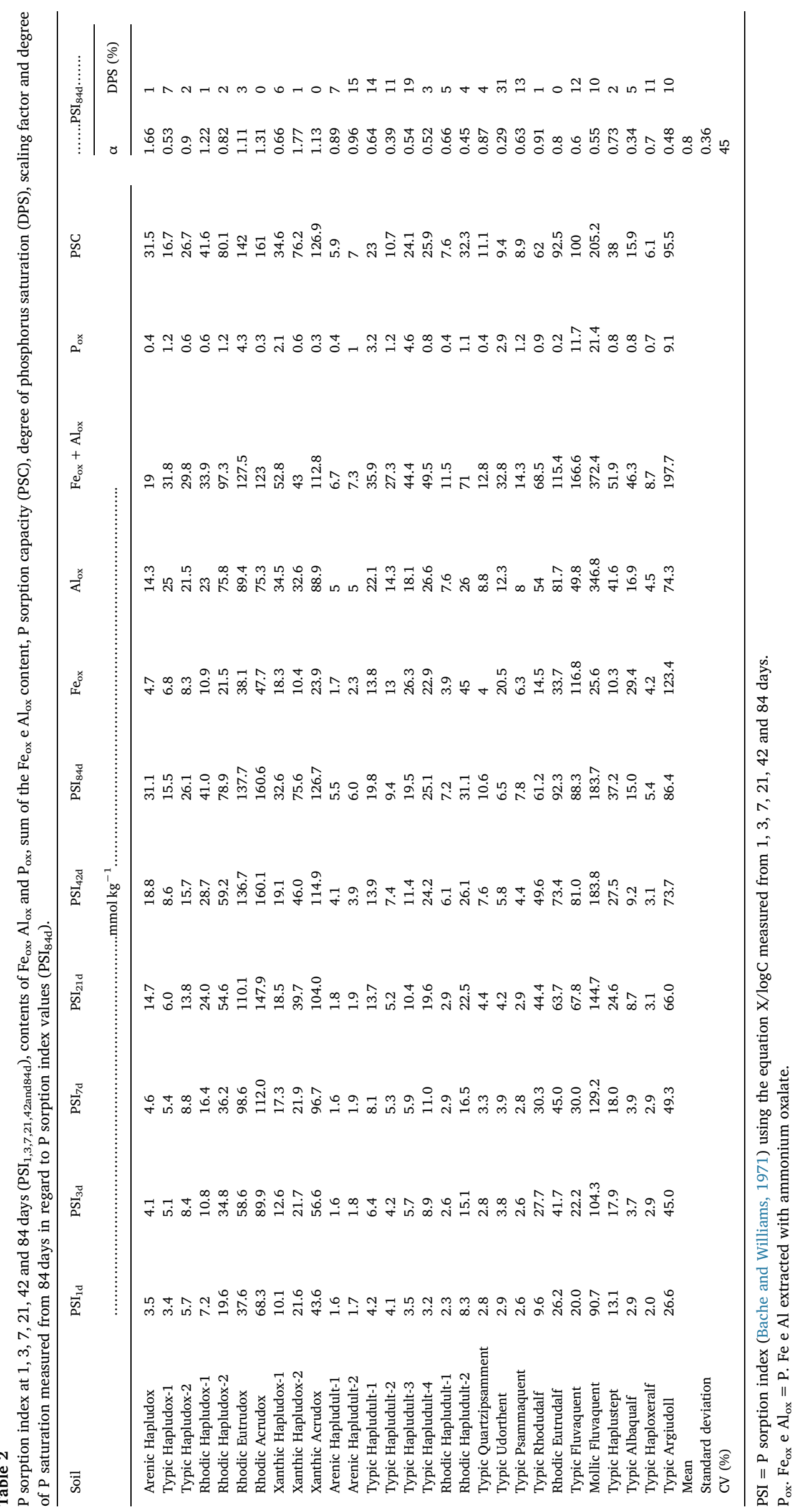



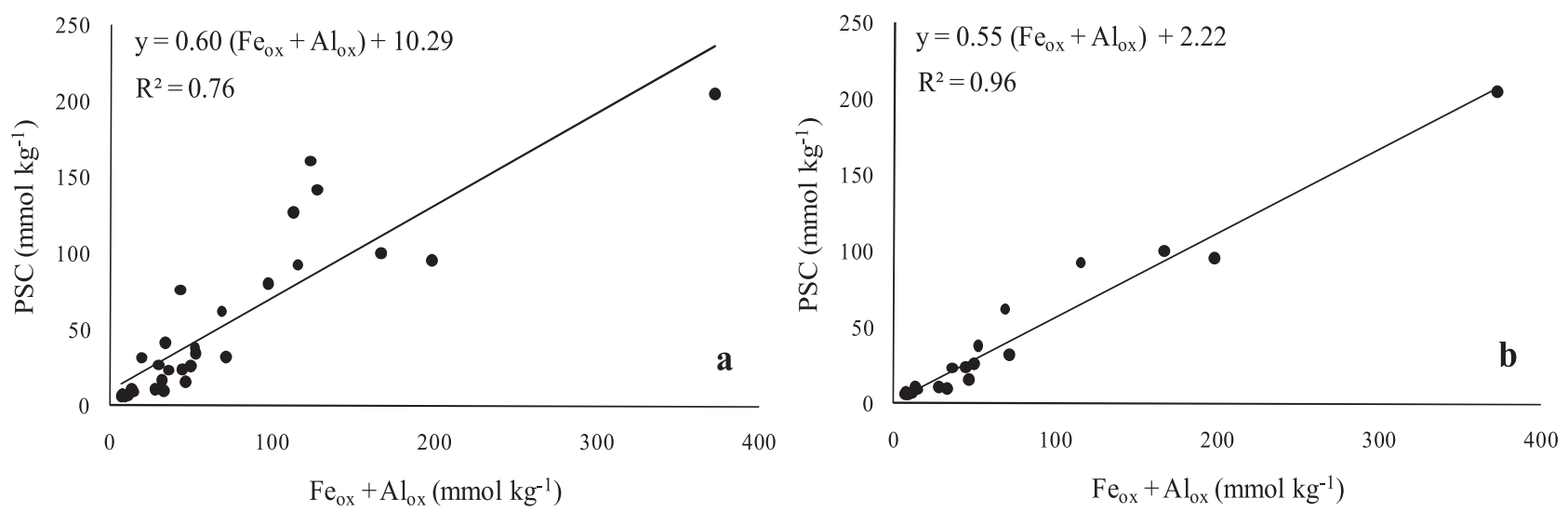

Fig. 1. Linear regression between (a) the sum of the oxides $\left(\mathrm{Fe}_{\mathrm{ox}}+\mathrm{Al}_{\mathrm{ox}}\right)$ and the PSC including Oxisols and (b) the sum of the oxides (Fe $\left.\mathrm{ox}+\mathrm{Al}_{\mathrm{ox}}\right)$ and the PSC excluding Oxisols.
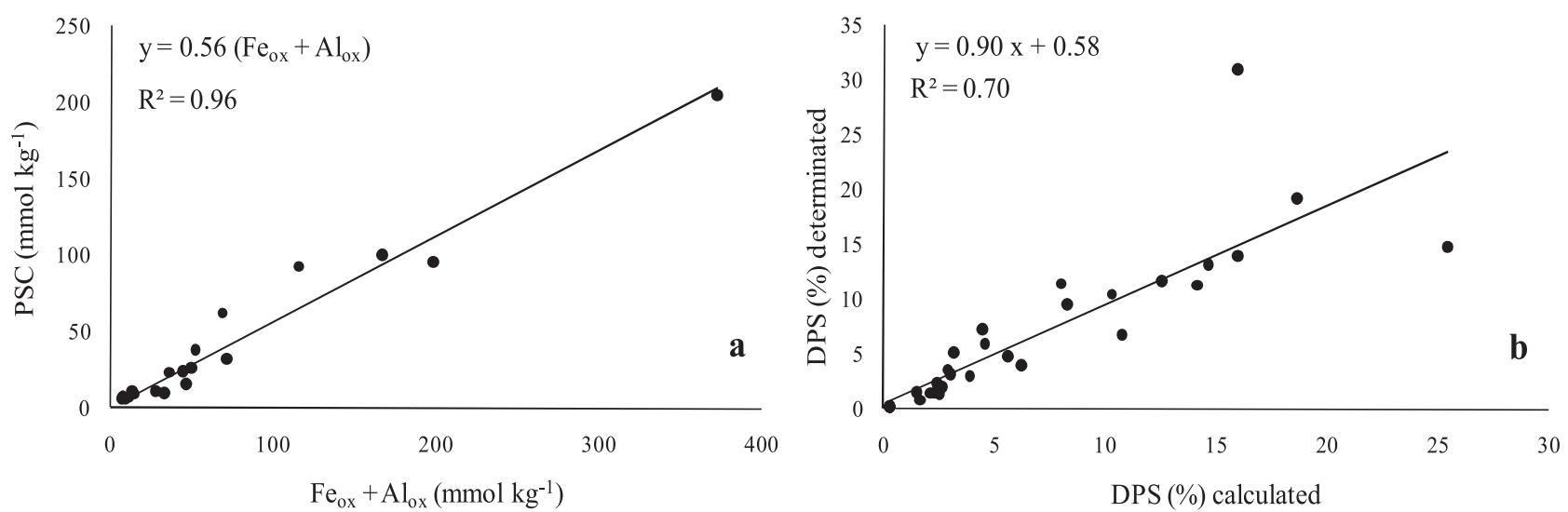

Fig. 2. (a) Linear regression between the sum of the oxides $\left(\mathrm{Fe}_{\mathrm{ox}}+\mathrm{Al}_{\mathrm{ox}}\right.$ ) and the PSC, excluding the Oxisols, and the straight line beginning at the chart's origin; (b) Linear regression between the DPS calculated DPS and the DPS determined.
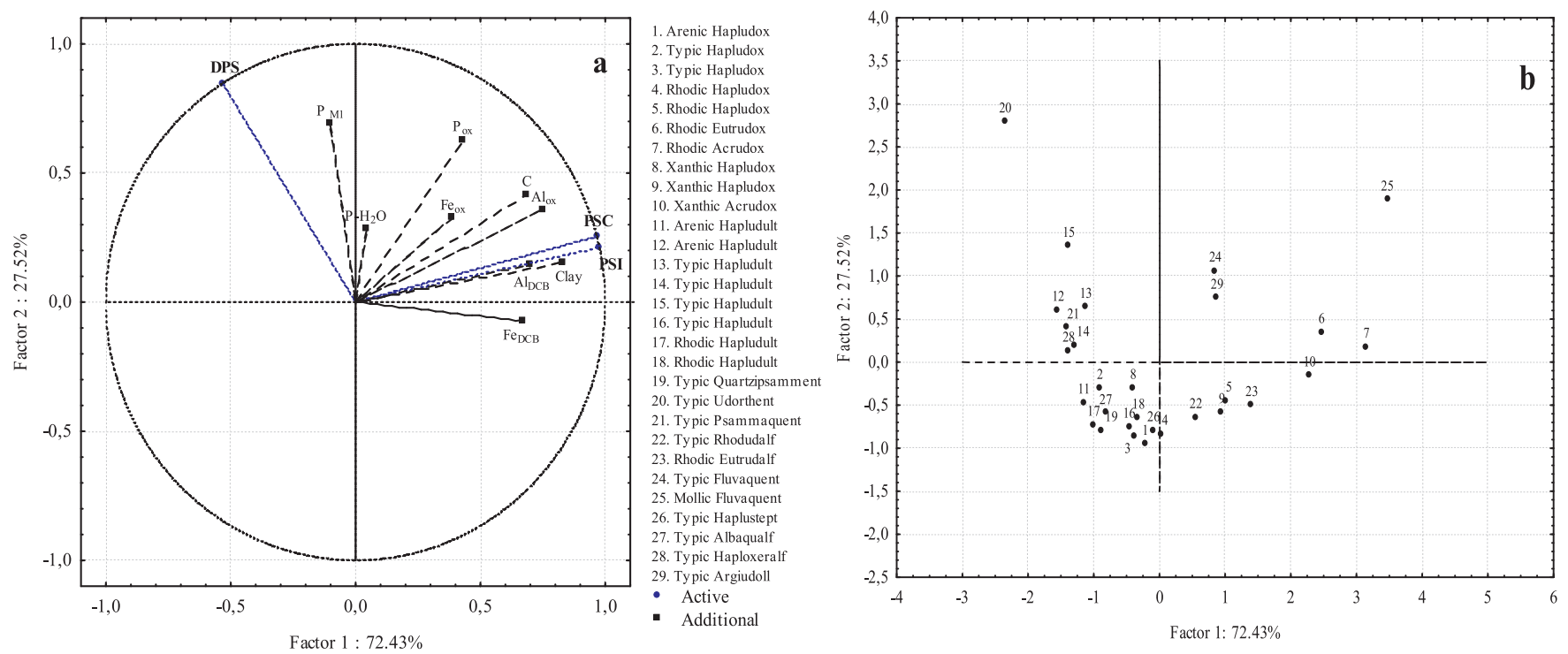

Fig. 3. Projection of the variables (a) and soil types (b) subjected to principal components analysis with a number of properties in all the soils studied (PC1).

emphasizes the observation that the poorly crystalline oxides were not the only factor affecting P adsorption in the Oxisols. Perhaps the most important one was the iron oxides considering their low percentage in comparison to crystalline oxides (Table 1). In Fig. 1b, the factor that determined the line intercept of the y-axis was positive and close to zero (2.21). Therefore, the trend line from the origin and a slope of 0.56 were considered to represent $\alpha$ for the other soils. The line had an excellent fit when calculating PSC (Fig. 2a). There was a good fit in Fig. $2 b\left(R^{2}=0.70\right)$ when regression was used to assess the correlation between the determined and the calculated DPS using the predicted $\alpha$ ( $\alpha=0.56$ ). Two out of the 29 points, however, were poorly predicted and had high DPS values (Typic Udorthent $=31$, the highest one, and 


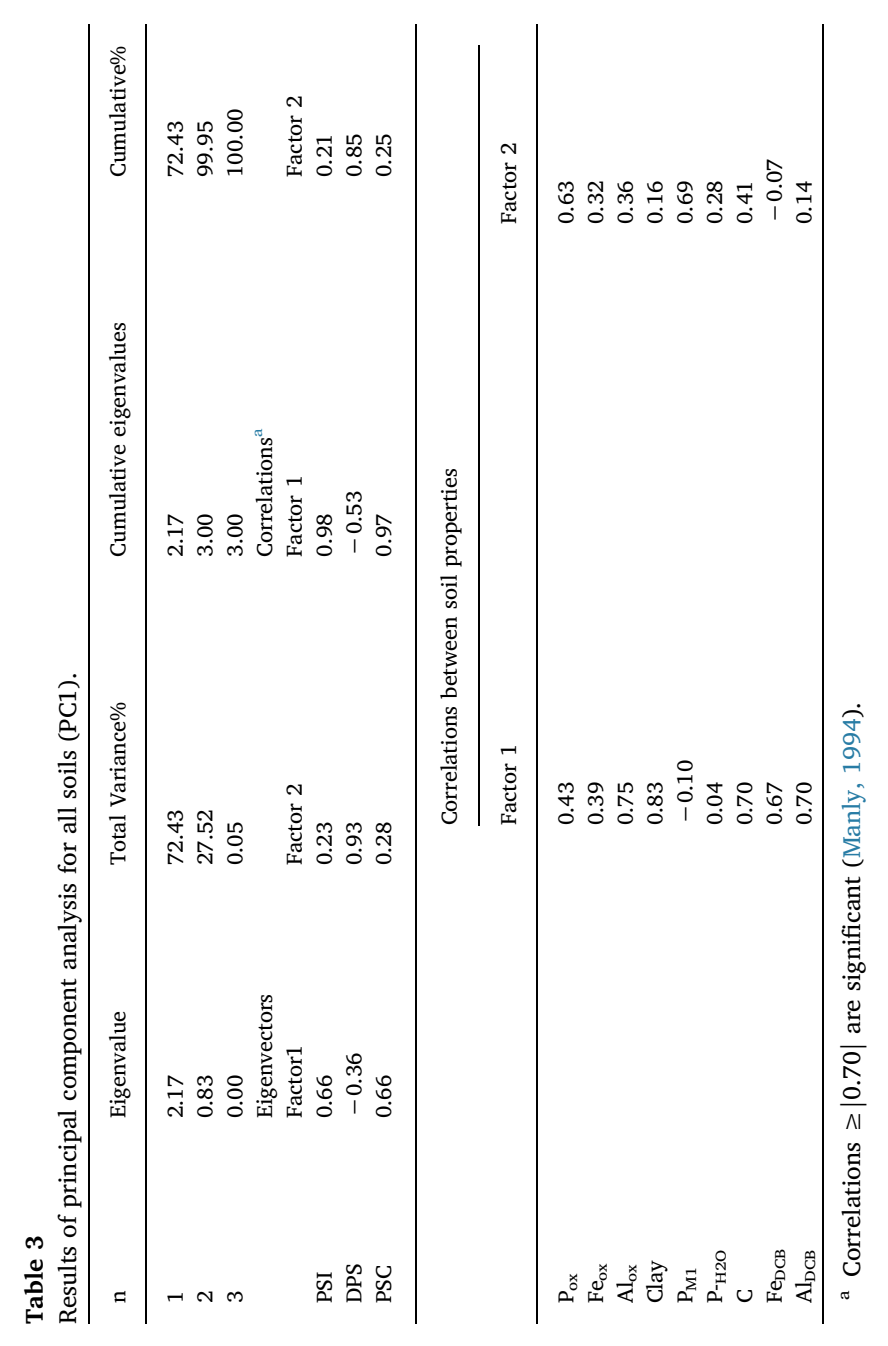

Arenic Hapludult-2 $=25$ ) and the lowest oxide contents. A representative value of $\alpha$ for highly weathered soils increases the viability of PSC and DPS assessment as an important tool for agricultural and environmental use.

Lower DPS values (Table 2) were found in the soil groups with high $\mathrm{P}$ adsorption capacity (Groups I and II). Oxisols and Alfisols were low in susceptibility to $\mathrm{P}$ loss due to their high adsorption potential, while Ultisols and Entisols were more susceptible to P loss. DPS did not exceed $7 \%$ for the Oxisols and the Alfisols. In the case of the Ultisols and the Entisols, DPS reached 31\% in Typic Udorthent (Table 2). In another study to assess the risk of P losses using DPS, Bortolon et al. (2016) evaluated eight of the most representative cropland soil types in southern Brazil and found DPS values ranging from 4.6 to $79.9 \%$, with an average of $28 \%$.

Oxisols and Alfisols had a high (still available adsorption capacity) with the $\mathrm{PSI}_{84 \mathrm{~d}}$ ranging from 15.5 to $160.7 \mathrm{mmol} \mathrm{kg}^{-1}$ of $\mathrm{P}$. On the other hand, this was at most $31.1 \mathrm{mmol} \mathrm{kg}^{-1}$ for Ultisols and Entisols (Table 2). Since the content of phosphate present in soil is, in most cases, not dramatically different for these soils (except the Fluvaquents), it is evident that the DPS is a different indicator for possible Plosses from $\mathrm{P}_{\mathrm{ox}}$.

Despite having PSI $_{84 \mathrm{~d}}$ values similar to those of the Oxisols and Alfisols, the Gleysols and Typic Argiudolls had higher DPS values compared to the initial adsorbed $\mathrm{P}$. These soils presented high levels of $\mathrm{P}_{\mathrm{ox}}, \mathrm{Fe}_{\mathrm{ox}}$ and $\mathrm{Al}_{\mathrm{ox}}$ (Table 2). Since they are less weathered soils, Gleysols and Typic Argiudolls had higher concentrations of poorly crystallized oxides and P linked to oxides. The Typic Haplustept, Typic Albaqualf and Typic Haploxeralf types had intermediate DPS values, ranging from 2 to $11 \%$.

After calculating the DPS, the results were grouped at a critical level of $\mathrm{P}$, which were obtained by correlating the DPS with the P dissolved or exported in a leach solution. These tend to increase rapidly with increases in the DPS (Casson et al., 2006). The values of these critical levels used in different countries vary within the range of $20-45 \%$ (Breeuwsma and Silva, 1992; De Smet et al., 1996; Nair et al., 2004; Butler and Coale, 2005; Nelson et al., 2005; Xu et al., 2014), with 25\% being the most used. Nair et al. (2004) determined the critical level for a range of soils in Florida, USA, and concluded that above a value of $20 \%$, the dissolved P content increased rapidly, becoming susceptible to losses. Paulter and Sims (2000) fixed the critical level at 30\% in the US. As Van Der Zee (1988) demonstrated, redistribution of P present in Dutch topsoils towards groundwater necessitates a safety margin, as expressed by a critical value of $25 \%$.

Ghosh et al. (2011) evaluated the impact of the application of biosolids on water quality and the DPS in Oxisols from the Brazilian savanna ("Cerrado"). The authors determined a critical level of $23 \%$ for the DPS according to the phosphorus saturation index (DPS $\left.{ }_{\mathrm{PSI}}\right)$ (equivalent to $\mathrm{DPS}_{\mathrm{SM} 1}$ of $16.5 \%$ ) corresponding to M1-P (P extracted with Mehlich 1 solution) of $44.5 \mathrm{mg} \mathrm{kg}^{-1}$ of $\mathrm{P}$ for this particular case, which could be taken as the threshold for P losses in these acidic soils (Ghosh et al., 2011). Because the DPS is an indicator in Brazil and is very close to the $25 \%$ used in the Netherlands, this value was chosen as the critical level for the soils used in our study. Thus, when using the DPS index, we observed that only the Typic Udorthent revealed a level of $\mathrm{P}$ content in soil that may imply a threat to water quality. Since the majority of the highly weathered soils had high $\mathrm{P}$ adsorption capacities, it can be assumed that the most important loss of $\mathrm{P}$ in humid tropical soils will be a result of runoff rather than leaching.

Various properties of the soils were taken into account in a principal component analysis (PCA) to assess which of them might best explain variations in the DPS, PSC and PSI parameters. The properties submitted to principal component analysis were $\mathrm{P}_{\mathrm{ox}}, \mathrm{Fe}$ and $\mathrm{Al}$ crystalline oxides $\left(\mathrm{Fe}_{\mathrm{DCB}}\right.$ and $\left.\mathrm{Al}_{\mathrm{DCB}}\right)$ and poorly crystallized $\left(\mathrm{Fe}_{\mathrm{ox}}\right.$ and $\left.\mathrm{Al}_{\mathrm{ox}}\right), \mathrm{P}$ content extracted with Mehlich 1 and water $\left(\mathrm{P}_{\mathrm{M} 1}\right.$ and $\left.\mathrm{P}_{\mathrm{H} 2 \mathrm{O}}\right)$, clay and $\mathrm{C}$ contents (Tables 1 and 2).

Fig. 3 shows a projection of the variables (a) and soil types (b) for all 

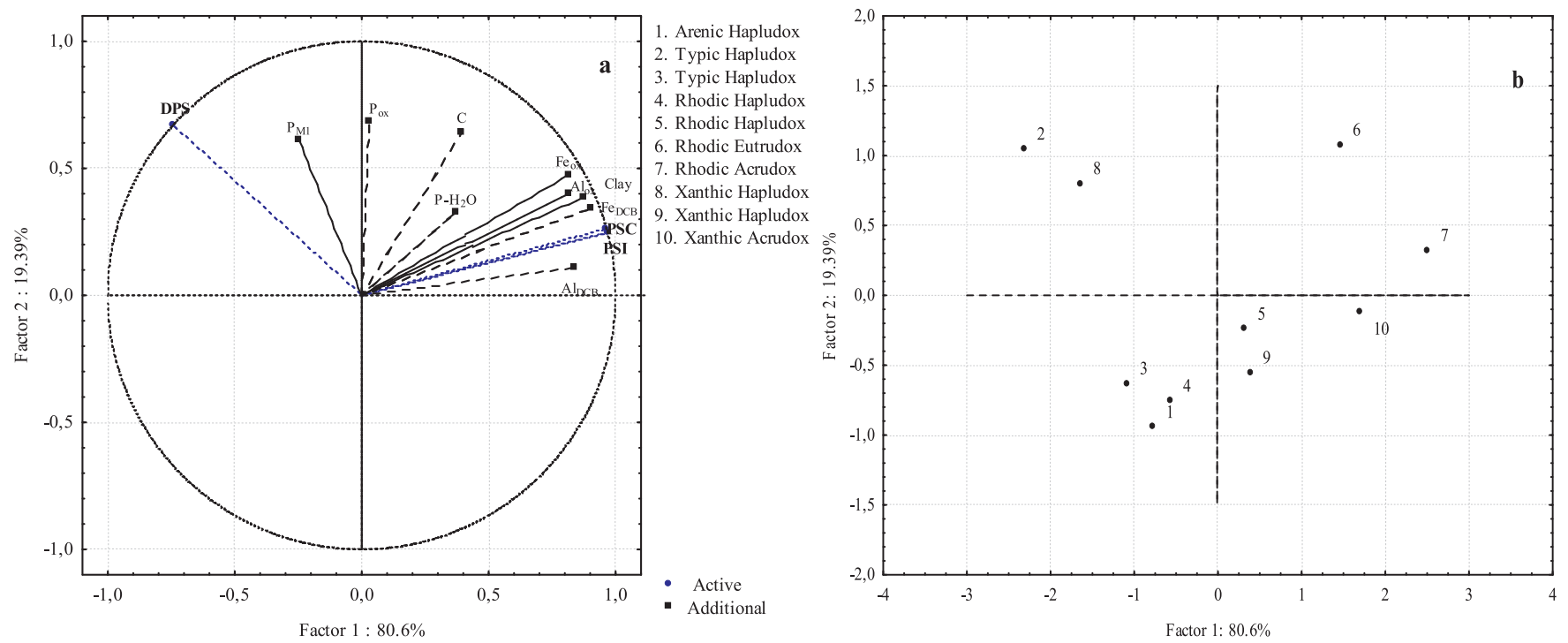

Fig. 4. Projection of the variables (a) and soil types (b) subjected to principal component analysis with a number of properties only in Oxisols (PC2).
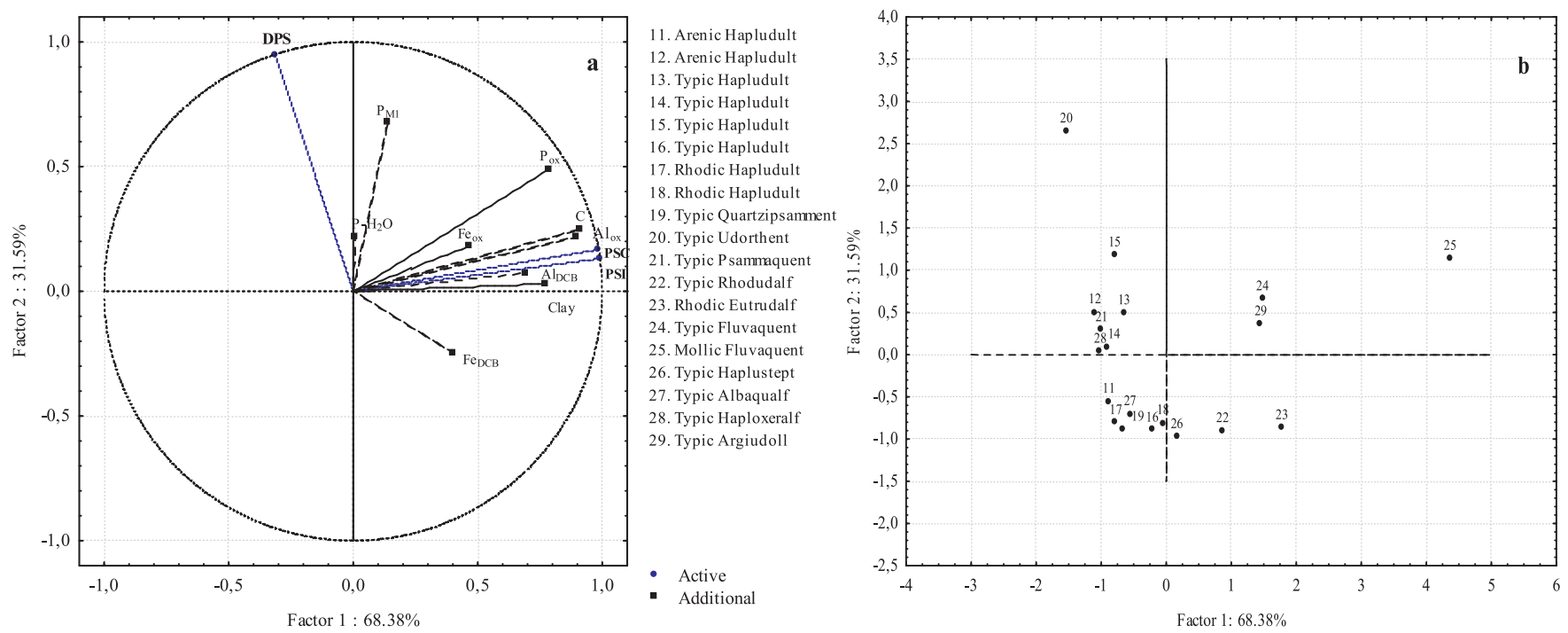

Fig. 5. Projection of the variables (a) and soil types (b) subjected to principal component analysis with a number of properties in the other soils (PC3).

the soils studied (PC1) and the values are presented in Table 3. Factor 1 (the horizontal axis in Fig. 3a) had an eigenvalue $\geq 1$, that explained $72 \%$ of the variation in results, and was influenced by PSI and PSC, which both had very similar values as the level of oxalate extractable $\mathrm{P}$ is low in most soils. The $\mathrm{Al}_{\mathrm{ox}}$, clay, $\mathrm{C}$ and $\mathrm{Al}_{\mathrm{DCB}}$ were the properties that showed the highest correlations with those variables $(\geq|0.70|)$. The influence of silicate minerals in clay fraction on $\mathrm{P}$ adsorption could be related to the specific surface area of the colloids, being higher in gibbsite, followed by kaolinite, goethite and hematite, which could then explain the important role of $\mathrm{Al}$ oxides in $\mathrm{P}$ adsorption (Mesquita Filho and Torrent, 1993). Eberhardt et al. (2008) studied the availability and retention of $\mathrm{P}$ in Oxisols from the Brazilian savanna under pasture using PCA to evaluate the influence of soil properties on the P dynamics. They concluded that crystalline and poorly crystallized $\mathrm{Fe}$ and $\mathrm{Al}$ oxides, the clay amounts and total $\mathrm{C}$ were those that were best related to $\mathrm{P}$ adsorption. The effect of total $\mathrm{C}$ on $\mathrm{P}$ adsorption may be linked to the fact that the $\mathrm{C}$ content in soil increases as a function of the clay content and clay would positively influence P adsorption (Eberhardt et al., 2008). However, that much iron and aluminum is also found to be associated with organic matter (Van Der Zee and Van Riemsdijk, 1988).

The $\mathrm{Fe}_{\mathrm{ox}}$ content had no significant correlation with the PSI and PSC variables. Valladares et al. (2003) found no significant correlation between the poorly crystallized forms of $\mathrm{Fe}$ and $\mathrm{P}$ adsorption in Oxisols, Ultisols and Inceptisols in Brazil and attributed this to the low $\mathrm{Fe}_{\mathrm{ox}}$ content levels in the soils studied for that particular case.

Factor 2 in Fig. 3a explained 27.5\% of the variation in results and was mainly influenced by the DPS in all soils studied. This factor did not show high correlation with the soil properties. The main contributors to this factor were found in two out of the P-fractions (oxalate and Mehlich extractable). $\mathrm{P}_{\mathrm{M} 1}$ values express the labile $\mathrm{P}$ in equilibrium with the soil solution and vary positively with the DPS. The $\mathrm{P}_{\mathrm{H} 2 \mathrm{O}}$ represents the $\mathrm{P}$ in solution. Therefore, a certain correlation between $\mathrm{P}_{\mathrm{H} 2 \mathrm{O}}$ and DPS was expected. However, the correlation coefficient was very low and did not express the relationship between the variables in this study, which can be attributed to possible interference with Mehlich 1 extractor or even a possible historic indication of $\mathrm{P}$ inputs.

Fig. 3b shows the grouping of soils as a function of the variables that exerted most influence. Soils to the left of the axis are most influenced by the DPS (same position as in Fig. 3a). Typic Udorthent is the soil that is closest to the DPS (farthest from the origin) as long as it has the highest DPS values. Soils with the highest DPS values have a low capacity for adsorbing elements, usually typified by sandy soils. Acidic 


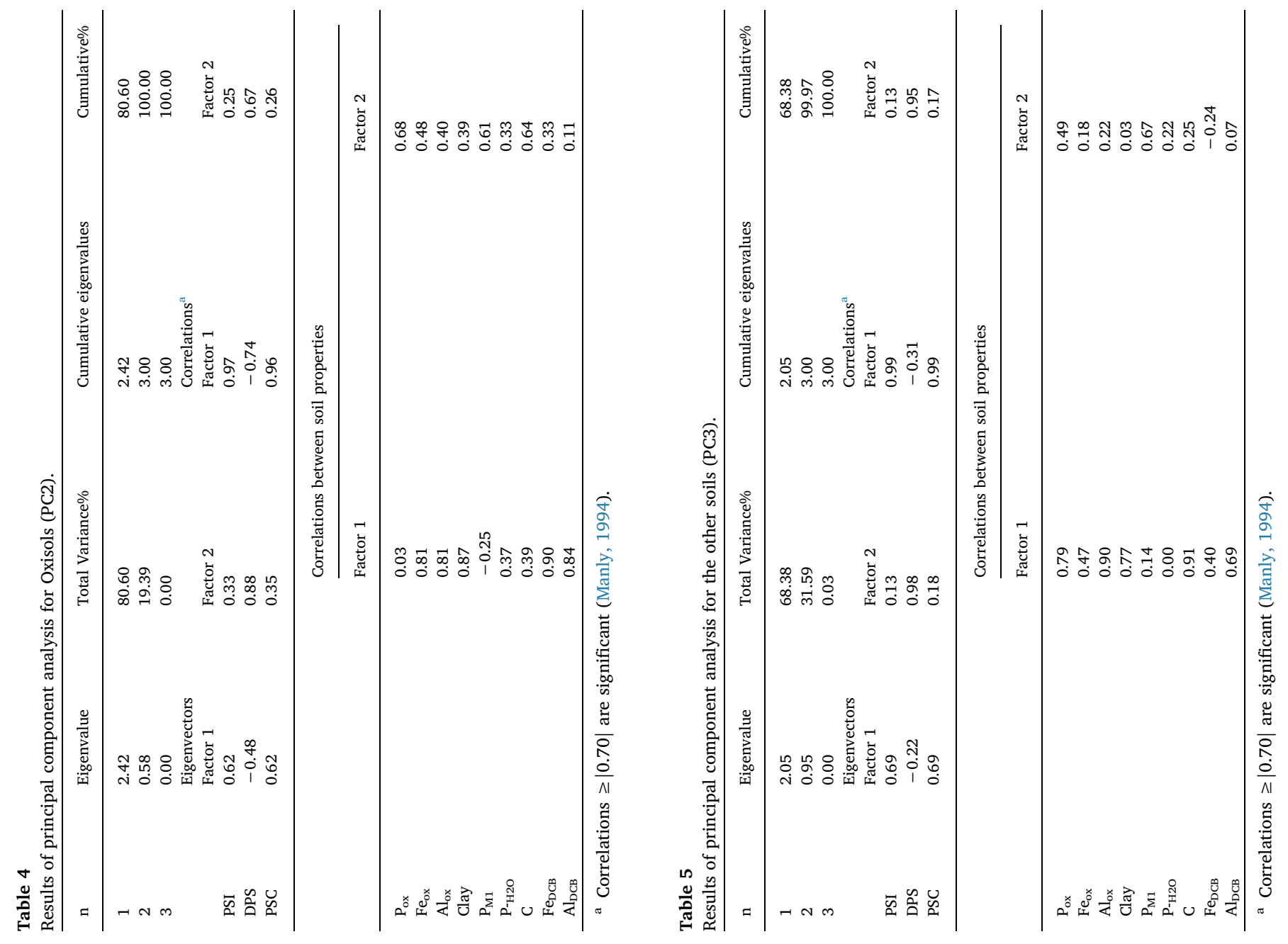


Table 6

Coefficients for multiple linear regressions of soil properties in relation to $\mathrm{P}$ soption capacity (PSC) and P sorption index at $84 \mathrm{~d}$ of contact $\left(\mathrm{PSI}_{84 \mathrm{~d}}\right)$.

\begin{tabular}{|c|c|c|c|c|c|}
\hline Parameter & Intercept & Properties & & & $\mathrm{R}^{2}$ \\
\hline (I) PSC & +10.29 & $\begin{array}{l}+0.60 \\
\mathrm{Fe}_{\mathrm{ox}}+\mathrm{Al}_{\mathrm{ox}}\end{array}$ & & & $0.76^{* \ldots * x}$ \\
\hline (II) PSC & +11.24 & $+0.52 \mathrm{Fe}_{\mathrm{ox}}$ & $\begin{array}{l}+0.62 \\
\mathrm{Al}_{\mathrm{ox}}\end{array}$ & & $0.76^{* \ldots 2 k x}$ \\
\hline (III) PSC & +3.99 & $+0.51 \mathrm{Fe}_{\mathrm{ox}}$ & $\begin{array}{l}+1.22 \\
\mathrm{Al}_{\mathrm{ox}}\end{array}$ & $-0.63 \mathrm{P}_{\mathrm{ox}}^{* * \ldots k}$ & $0.87^{* * * *}$ \\
\hline (IV) PSC & -0.17 & $+0.49 \mathrm{Al}_{\mathrm{ox}}$ & $\begin{array}{l}+0.01 \\
\mathrm{Fe}_{\mathrm{DCB}}\end{array}$ & $+0.04 \mathrm{Al}_{\mathrm{DCB}}$ & $0.94^{* \ldots * n}$ \\
\hline (V) $\mathrm{PSI}_{84 \mathrm{~d}}$ & +1.96 & $+0.32 \mathrm{Fe}_{\mathrm{ox}}$ & $\begin{array}{l}+0.85 \\
\mathrm{Al}_{\mathrm{ox}}\end{array}$ & & $0.94^{* * \cdots *}$ \\
\hline
\end{tabular}

$* * p<0.01$

$* * * p<0.001$.

sandy soils are more susceptible to $\mathrm{P}$ loss when subjected to intense applications of phosphate fertilizers, which can pose risks to the environment (Nair et al., 2004; De Bolle et al., 2013). To the right of the axis are the soils with higher PSI and PSC values.

PCA was also performed separately on the Oxisols (Fig. 4) as well as on the other soils (Fig. 5). In the Oxisols, Factor 1 was the source for $81 \%$ of the variation in results, also influenced by the PSI and PSC (Fig. 4a). The $\mathrm{Fe}_{\mathrm{ox}}, \mathrm{Al}_{\mathrm{ox}}$, clay, $\mathrm{Fe}_{\mathrm{DCB}}$ and $\mathrm{Al}_{\mathrm{DCB}}$ properties represented the main components relevant to P adsorption. Fontes and Weed (1996) studied the relationship of $\mathrm{P}$ adsorption to the mineral composition of Brazilian Oxisols and concluded that the main properties related to $\mathrm{P}$ adsorption were the $\mathrm{Fe}_{\mathrm{DCB}}, \mathrm{Al}_{\mathrm{DCB}}$ e $\mathrm{Al}_{\mathrm{Ox}}$ content, which, in general, corroborates the results of this study.

When soils were not categorized into groups, it was noticed that $\mathrm{Fe}_{\mathrm{DCB}}$ exerted influence on $\mathrm{P}$ adsorption, probably due to its occurrence in quantity in Oxisols (Table 1). The participation of crystalline oxides in $\mathrm{P}$ adsorption in Oxisols is evident from the high amount adsorbed even when low levels of poorly crystallized oxides were observed. This feature is very important in Oxisols, which account for approximately $60 \%$ of the soil in areas of agricultural potential in Brazil (Soares and Alleoni, 2008) and are subject to high amounts of phosphate fertilizers. This being the case possible $\mathrm{P}$ saturation has increased over time and continuous application of phosphorus has increased the amount of soluble $\mathrm{P}$, in turn increasing its susceptibility to move along the soil profile and cause environmental impact.

Even in relation to Factor 1, C content had no significant correlation with the PSC and the PSI. Owing to their highly-weathered profile, Oxisols contain naturally low levels of $\mathrm{C}$ (Table 1) and their participation in $\mathrm{P}$ adsorption was not efficient. Factor 2 explained only $19 \%$ of the variation in the results and was influenced by the DPS. However, none of the properties showed significant correlation (Table 4).

In the other soils, $\mathrm{C}$ appeared again as one of the major components (Table 5), probably due to the high C levels in Gleysols, Alfisols, a number of Ultisols and Typic Argiudoll. Factor 1 explained 68\% of the variation in the results, and the properties that showed significant correlation with the other soils were $\mathrm{P}_{\mathrm{ox}}, \mathrm{Al}_{\mathrm{ox}}$, clay and C (Fig. 5).

Crystalline structures of minerals were probably no longer the major components in the other soils, at least for the topsoil layer $(0-20 \mathrm{~cm})$ studied. The $\mathrm{Al}_{\mathrm{DCB}}$, however, was very close to showing a degree of correlation $\geq|0.70|$ (Table 5). The $\mathrm{Al}$ oxides stand out in $\mathrm{P}$ adsorption, as their specific surface is higher than for iron oxides (Mesquita Filho and Torrent, 1993), allowing for more interaction with the P. Factor 2 was represented by the DPS, and once again, there was no significant correlation with soil properties (Table 5).

The $\mathrm{P}_{\mathrm{ox}}$ was directly proportional to the DPS and inversely to the PSI and PSC, as observed in the projections of the variables in which the PSI and PSC influenced the eigenvectors in Factor 1 while the DPS exerted an influence on Factor 2. Low levels of $\mathrm{P}_{\mathrm{ox}}$ may have influenced the lack of correlation with the DPS in our study.

As showed in the PCA, the DPS did not correlate well with the soil properties, as it depended on the concentration of poorly crystallized oxides and soil adsorption capacity. In order to facilitate the estimation of the DPS value, equations derived from multiple linear regressions were calculated from the properties determined by PCA (Table 6).

Previously, we had used linear regression to calculate the PSC of the soils (Figs. 1 and 2). However, the correlation coefficient was not a satisfactory fit $\left(\mathrm{R}^{2}=0.76 * * *\right.$, Eq. (1)) when using the sum of the content of the oxides $\left(\mathrm{Fe}_{\mathrm{ox}}+\mathrm{Al}_{\mathrm{ox}}\right)$. Starting from this point, we tested for multiple correlation between oxides separately $\left(\mathrm{Fe}_{\mathrm{ox}}\right.$ and $\left.\mathrm{Al}_{\mathrm{ox}}\right)$ in order to improve the fit, but the coefficient remained unchanged $\left(\mathrm{R}^{2}=0.76 * * *\right.$, Eq. (2)). However, Maguire et al. (2001) also reviewed the $\mathrm{Fe}$ and $\mathrm{Al}$ variables separately and observed that the correlation coefficient with the PSC increased from 0.89 to 0.91 , showing a significant change from the sum of the oxides.

Definitely, the $\mathrm{P}_{\mathrm{ox}}$ content improved the fit $\left(\mathrm{R}^{2}=0.87^{* * *}\right.$, Eq. (3)). In Eq. (4), as well as the poorly crystalline oxide content, the crystalline content was also used to better represent the Oxisols, leading to a rather high correlation $\left(\mathrm{R}^{2}=0.94^{* * *}\right.$, Eq. (4)), which yielded a more accurate PSC prediction. Again, we observed the influence of crystalline oxides on the Oxisols and the low representation of the poorly crystallized oxides. Another variable tested was the $\mathrm{PSI}_{84 \mathrm{~d}}$ (Table 4, Eq. (5)), which produced an excellent adjustment using only $\mathrm{Fe}_{\mathrm{ox}}$ and $\mathrm{Al}_{\mathrm{ox}}$
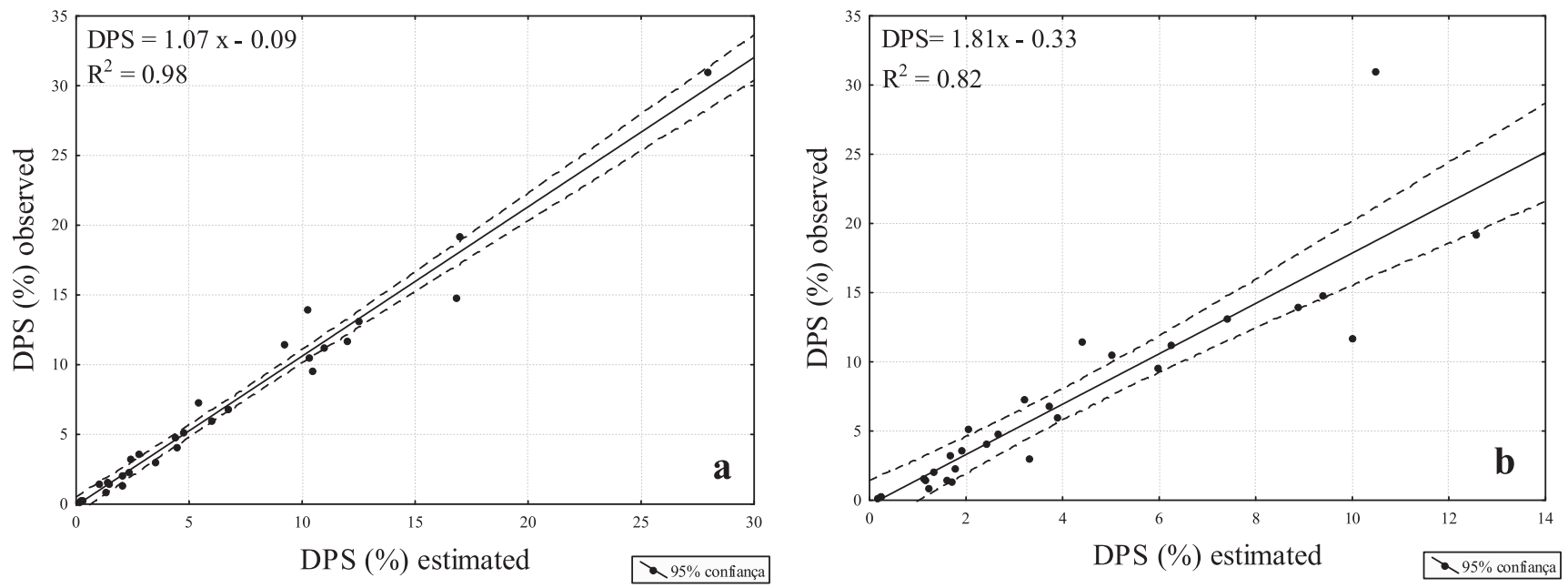

Fig. 6. Relationship between the DPS observed and estimated by Eq. (4) (a) and V (b) for all soils. 


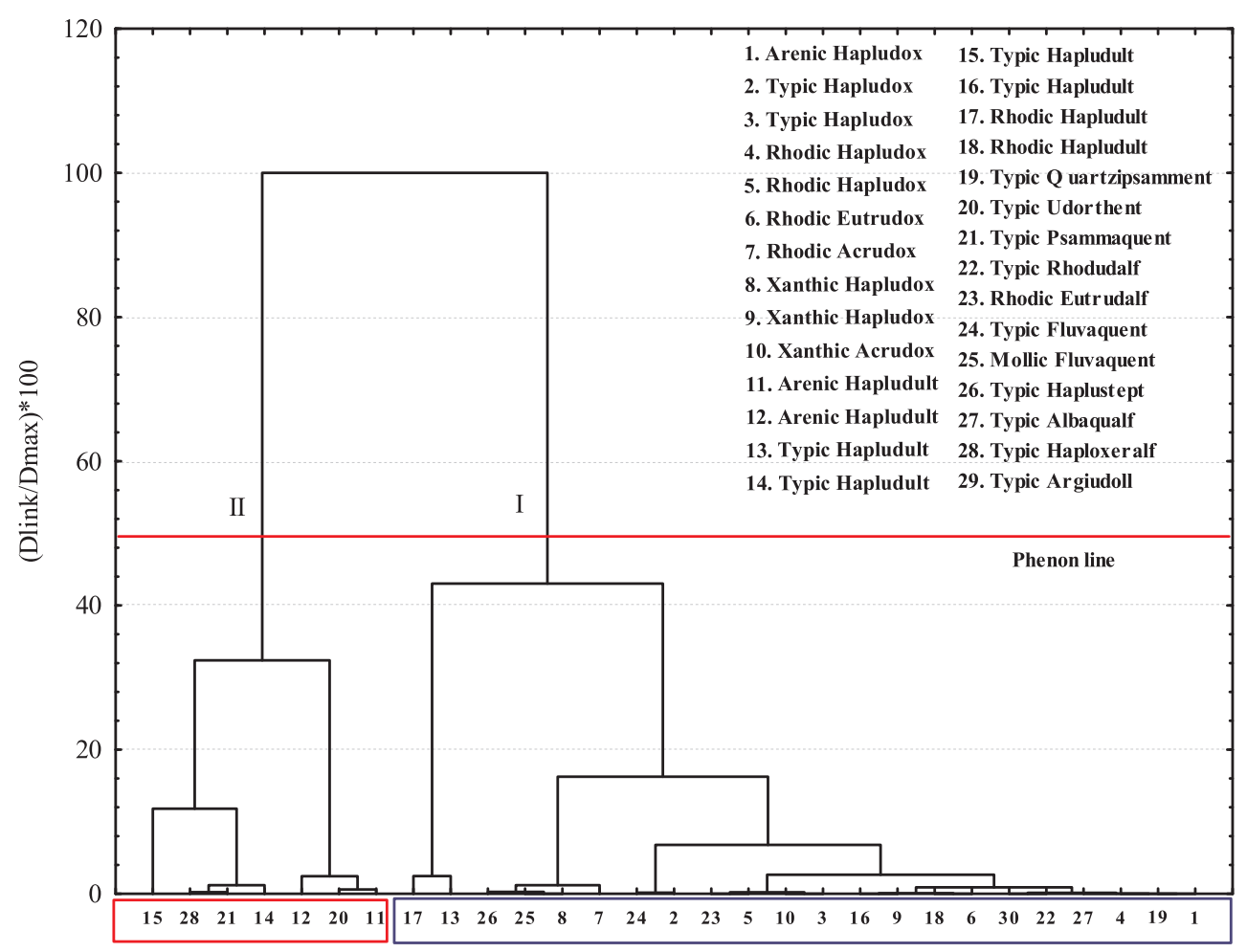

Fig. 7. Cluster analysis of the soil based on the PSI, PSC and DPS in accordance with the Euclidean distance determined by Pearson's correlation method.

Table A1

Phosphorus adsorption capacity and its respective conversions into $\mathrm{mmol} \mathrm{kg}^{-1}$ of $\mathrm{P}$ and phosphate anion $\left(\mathrm{PO}_{4}{ }^{3-}\right)$.

\begin{tabular}{lll}
\hline$\ldots \ldots . \mathrm{mg} \mathrm{kg}^{-1} \ldots \ldots$ & $\ldots \ldots \ldots \ldots \ldots \mathrm{mmol} \mathrm{kg}^{-1} \ldots \ldots \ldots \ldots \ldots \ldots$ & \\
\cline { 2 - 3 } $\mathrm{S}_{\max }$ & $\mathrm{P}$ & $\mathrm{PO}_{4}{ }^{3-}$ \\
\hline 2000 & 64.57 & 21.06 \\
1000 & 32.29 & 10.53 \\
500 & 16.14 & 5.26 \\
200 & 6.46 & 2.11 \\
\hline
\end{tabular}

Smax: P adsorption capacity.

$\mathrm{P}$ (Phosphorus), mass molar $=30.973762 \mathrm{mg} \mathrm{mmol}^{-1}$.

$\mathrm{O}$ (Oxygen), mass molar $=15.9994 \mathrm{mg} \mathrm{mol}^{-1}$.

$\mathrm{PO}_{4}{ }^{3-}$, mass molar $=94.971362 \mathrm{mg} \mathrm{mmol}^{-1}$.

$\left(\mathrm{R}^{2}=0.94 * * *\right)$.

The correlation between the observed DPS and the calculated DPS from the properties mentioned above was made possible by using Eqs. (4) and (5), (Fig. 6a and b), being $\mathrm{Al}_{\mathrm{ox}}, \mathrm{Fe}_{\mathrm{DCB}}$ and $\mathrm{Al}_{\mathrm{DCB}}$ from Eq. (4) and $\mathrm{Fe}_{\mathrm{ox}}$ e $\mathrm{Al}_{\mathrm{ox}}$ from Eq. (5). The coefficient of determination was high $\left(\mathrm{R}^{2}=0.98\right)$ when Eq. (4) was used to calculate the DPS (Fig. 6a), suggesting strong influence of the crystalline structures on $\mathrm{P}$ adsorption in humid tropical soils as well as the influence of poorly crystallized $\mathrm{Al}$ oxides. In Fig. $6 \mathrm{~b}$ the DPS calculated by Eq. (5) had a coefficient of determination lower than that in Fig. 6a, and shows that the adjustment was not efficient at a number of points. The use of Eq. (4), in addition to presenting the best fit, directly provided the PSC, which enables the use of the DPS.

A soil dendrogram was drawn considering the DPS and the PSC parameters, in a Pearson correlation, including all the soils studied in order to illustrate the distribution of the soils studied as a function of susceptibility to P loss (Fig. 7). The fenon line (midline) is the dividing line at half the maximum Euclidean distance. This line separates the soil types studied and determines the number of groups to be formed. In this case, the dendrogram was separated into the formation of two groups (I and II). Group I separated the soils that do not appear to have a high degree of susceptibility to P loss as per the PSC and the DPS. In contrast, Group II brought together the most susceptible soils. The soils comprising Group I had low DPS and high PSC values, implying that the adsorption capacity was still very large. On the other hand, Group II soils had a higher DPS, a lower PSC and, thus, presented greater susceptibility to P loss.

\section{Conclusions}

1. The poorly crystalline fractions of $\mathrm{Fe}$ and $\mathrm{Al}$ oxides for most Oxisols do not lead to one scaling factor $(\alpha)$, and, therefore, may be poor predictors of the PSC.

2. In the other soils, the value of $\alpha=0.56$ was found to be reasonable for estimating the PSC, and the DPS calculated based on such an index showed high correlation with the DPS determined.

3. In Oxisols, the high $\mathrm{P}$ adsorption potential was due to the high concentrations of crystalline oxides. In the other soils, especially in sandy soils, the DPS can be used as an estimate of agri-environmental P loss risk in Brazil.

4. The properties related to the adsorption of $P$ varied depending on the soil types, particularly in Oxisols, and the DPS had no significant 


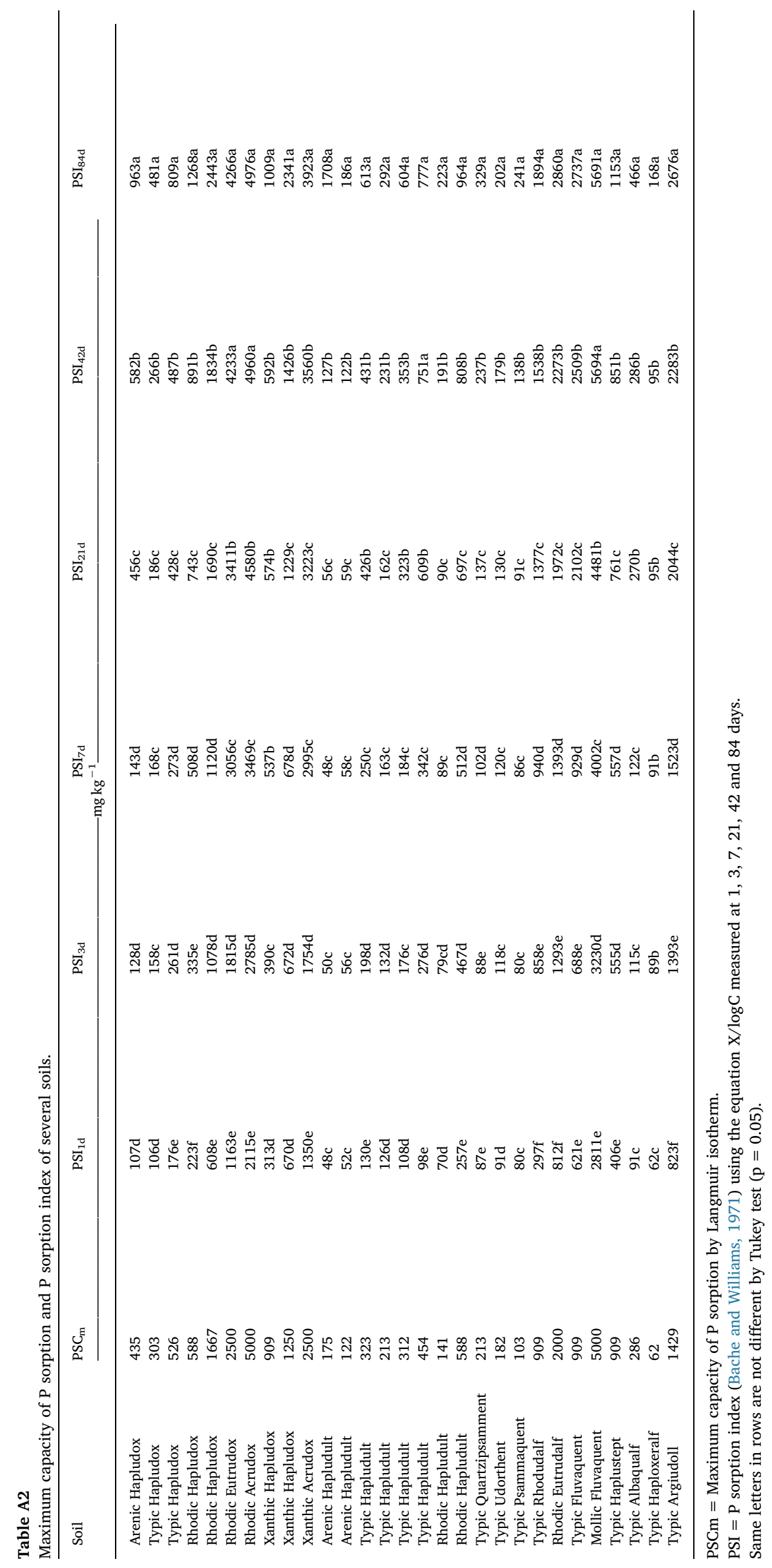


correlation with any of these properties.

5. Only the Typic Udorthent exceeded the critical threshold of $23 \%$, and 7 out of 29 soils had a medium susceptibility to P loss risk and potential eutrophication of surface waters.

\section{Appendix A}

See Tables A1 and A2.

\section{References}

Alleoni, L.R.F., Fernandes, A.R., Campos, M., 2014. Degree of phosphorus saturation of an Oxisol amended with biosolids in a long-term field experiment. Environ. Sci. Pollut. Res. 21, 5511-5520.

Anderson, T.W., 2003. An Introduction to Multivariate Statistical Analysis. John Wiley, New York: Hoboken.

Bache, B.W., Williams, E.G., 1971. A phosphate sorption index for soils. J. Soil Sci. 22, 289-301.

Beauchemin, S., Simard, R.R., 1999. Soil phosphorus saturation degree: review of some indices and their suitability for P management in Québec. Can. J. Soil Sci. 79, 615-625.

Borda, T., Celi, L., Zavattaro, L., Sacco, D., Barberis, E., 2011. Effect of agronomic management on risk of suspended solids and phosphorus losses from soil to waters. J. Soils Sed. 11, 440-451.

Bortolon, L., Ernani, P.R., Bortolon, E.S.O., Gianello, C., Almeida, R.G.O.D., Welter, S., Rogeri, D.A., 2016. Degree of phosphorus saturation threshold for minimizing P losses by runoff in cropland soils of Southern Brazil. Pesquisa Agropecuária Brasileira 51, 1088-1098.

Breeuwsma, A., Silva, S., 1992. Phosphorus Fertilization and Environmental Effects in the Netherlands and the Po Region (Italy). Winand Staring Centre for Integrated Land, Soil and Water Research, Wageningen 39 p. (Report, 57).

Butler, J.S., Coale, F.J., 2005. Phosphorus leaching in manure-amended atlantic coasta plain soils. J. Environ. Qual. 34, 370-381.

Casson, J.P., Bennett, D.R., Nolan, S.C., Olson, B.M., Ontkean, G.R., 2006. Degree of phosphorus saturation thresholds in manure-amended soils of Alberta. J. Environ. Qual. 35, 2212-2221.

De Bolle, S., De Neve, S., Hofman, G., 2013. Rapid redistribution of P to deeper soil layers in P saturated acid sandy soils. Soil Use Manag. 29, 76-82.

de Campos, M., Antonangelo, J.A., Alleoni, L.R.F., 2016. Phosphorus sorption index in humid tropical soils. Soil Tillage Res. 156, 110-118.

De Smet, J., Hofman, G., Vanderdeelen, J., Van Meirvenne, M., Baert, L., 1996. Phosphate enrichment in the sandy loam soils of West-Flanders, Belgium. Fert. Res. 43, 209-215.

Eberhardt, D.N., Vendrame, P.R.S., Becquer, T., Guimarães, M.F., 2008. Influence of particle size and mineralogy on phosphorus retention in Oxisols under pasture at the Cerrado. Rev. Bras. Cienc. Solo 32, 1009-1016 (in Portuguese).

Fontes, M.P.F., Weed, S.B., 1996. Phosphate adsorption by clays from Brazilian Oxisols: relationships with specific surface area and mineralogy. Geoderma 72, 37-51.

Freese, D., Van Der Zee, S.E.A.T.M., Van Riemsdijk, W.H., 1992. Comparison of different models for phosphate sorption as a function of the iron and aluminium oxides of soils. J. Soil Sci. 43, 729-738.

Freese, D., Van Riemsdijk, W.H., Van Der Zee, S.E.A.T.M., 1995. Modelling phosphatesorption kinetics in acid soils. Eur. J. Soil Sci. 46, 239-245.

Gee, G.W., Or, D., 2002. Particle-size analysis. In: Dane, J.H., Toop, G.C. (Eds.), Methods of Soil Analysis: Physical Methods. Soil Sci. Soc. Am. pp. 255-293 (Book Series no 5).

Ghosh, A.K., Barbosa, J., Silva, I.R., 2011. An environmental threshold of soil test P and degree of P saturation of Brazilian Oxisols. Clean Soil Air Water 39, 421-427.

Ige, D.V., Akinremi, O.O., Flaten, D.N., Ajiboye, B., Kashem, M.A., 2005. Phosphorus sorption capacity of alkaline Manitoba soils and its relationship to soil properties. Can. J. Soil Sci. 85, 417-426.

Kaiser, H.F., 1958. The varimax criterion for analytic rotation in factor analysis. Psychometrika 23, 187-200.

Kuo, S., 1996. Phosphorus. In: Sparks, D.L. (Ed.), Methods of Soil Analysis: Part 3-

\section{Acknowledgements}

Coordination for the Improvement of Higher Education Personnel (CAPES), National Council for Scientific and Technological Development (CNPq) and University of Sao Paulo (USP) for providing partial funding for the field and laboratory work.
Chemical Methods. SSSA, Madison, WI, pp. 869-919.

Liu, C., Kroeze, C., Hoekstra, A.Y., Gerbens-Leenes, W., 2012. Past and future trends in grey water footprints of anthropogenic nitrogen and phosphorus inputs to major world rivers. Ecol. Indic. 18, 42-49.

Lookman, R., Freese, D., Merckx, R., Vlassak, K., Van Riemsdijk, W.H., 1995. Long-term kinetics of phosphate release from soil. Environ. Sci. Technol. 29, 1569-1575.

Lookman, R., Jansen, K., Merckx, R., Vlassak, K., 1996. Relationship between soil properties and phosphate saturation parameters: a transect study in northern Belgium. Geoderma 69, 265-274.

Maguire, R.O., Foy, R.H., Bailey, J.S., Sims, J.T., 2001. Estimation of the phosphorus sorption capacity of acidic soils in Ireland. Eur. J. Soil Sci. 52, 479-487.

Manly, B.F.J., 1994. Multivariate Statistical Methods: A Primer, 2nd ed. Chapman \& Hall, New York 215 p.

McGechan, M.B., Lewis, D.R., 2002. Sorption of phosphorus by soil, part 1: principles, equations and models. Biol. Eng. 82, 1-24.

Mehra, J.A., Jackson, M.L., 1960. Iron oxides removal from soils and clays by dithionitecitrate system buffered with sodium bicarbonate. Clays Clay Miner. 5, 317-327.

Mesquita Filho, M.V., Torrent, J., 1993. Phosphate sorption as related to mineralogy of a hydrosequence of soils from Cerrado region (Brazil). Geoderma 58, 107-123.

Murphy, J., Riley, J.R., 1962. A modified single solution method for the determination of phosphate in natural waters. Anal. Chim. Acta 27, 31-36.

Nair, V.D., Portier, K.M., Graetz, D.A., Walker, M.L., 2004. An environmental threshold for degree of phosphorus saturation in sandy soils. J. Environ. Qual. 33, 107-113.

Nelson, D.W., Sommer, L.E., 1982. Total carbon, organic carbon, and organic matter. In: Page, A.L. (Ed.), Methods of Soil Analysis. Am. Soc. Agron., Madison, pp. 539-579.

Nelson, N.O., Parsons, J.E., Mikkelsen, R.L., 2005. Field-scale evaluation of phosphorus leaching in acid sandy soils receiving swine waste. J. Environ. Qual. 34, 2024-2035.

Paulter, M.C., Sims, J.T., 2000. Relationships between soil test phosphorus, soluble phosphorus, and phosphorus saturation in Delaware soils. Soil Sci. Soc. Am. J. 64, 765-773.

Schoumans, O.F., 2009. Determination of the degree of phosphorus saturation in noncalcareous soils. In: Kovar, J.L., Pierzynski, G.M. (Eds.), Methods of Phosphorus Analysis for Soils, Sediments, Residuals and Waters. Virginia Tech University (Southern Cooperative Series Bulletin, 408), Blacksburg, pp. 29-33.

Soares, M.R., Alleoni, L.R.F., 2008. Contribution of soil organic carbon to the ion exchange capacity of tropical soils. J. Sustain. Agric. 32, 439-462.

Soil Survey Staff, 1999. United States department of agriculture and natural resources conservation service. Soil Taxonomy: A Basic System of Soil Classification for Making and Interpreting Soil Surveys. Agriculture Handbook No 436. U.S. Government Printing Office, Washington, DC.

Statsoft, 2005. Statistica 7.0 Software. Tucksa.

Valladares, G.S., Pereira, M.G., Anjos, L.H.C., 2003. P sorption in low activity clay soils. Bragantia 62, 111-118 (in Portuguese).

Van Der Zee, S.E.A.T.M., Van Riemsdijk, W.H., 1988. Model for long-term phosphate reaction kinetics in soil. J. Environ. Qual. 17, 35-41.

Van Der Zee, S.E.A.T.M., 1988. Transport of reactive contaminants in heterogeneous soil systems. PhD Thesis. Wageningen Agricultural University 283 pp. 4 appendices.

Wang, Y.T., Zhang, T.O., Hu, S.C., Tan, C.S., O'halloran, I.P., Drury, C.F., Reid, D.K., Ma, B.L., Ball-Coelho, B., Lauzon, J.D., Reynolds, W.D., Welacky, T., 2010. Estimating dissolved reactive phosphorus concentration in surface runoff water from major Ontario soils. J. Environ. Qual. 39, 1771-1781.

Xu, G., Sun, J.C., Shao, H., Chang, S.X., 2014. Biochar had effects on phosphorus sorption and desorption in three soils with differing acidity. Ecol. Eng. 62, 54-60. 